\title{
ANALYSIS ON THE CHARACTERISTICS OF EX-MINING SOIL AFTER 5 YEARS AND 10 YEARS OF REVEGETATION
}

\author{
LULU YUNINGSIH ${ }^{1,2)}$, HERMANSYAH ${ }^{1,3)}$, EDDY IBRAHIM $^{1,4)}$ AND MARSI $^{1,5)}$ \\ ${ }^{1)}$ Graduate School of Enviromental Science, University of Sriwijaya, Jl. Padang Selasa, Bukit Besar, Palembang, South \\ Sumatera, 30139, Indonesia \\ ${ }^{2)}$ Forestry Study Program, Muhammadiyah University of Palembang, Jl. Jenderal A. Yani, Plaju, Palembang, South \\ Sumatera, 30263, Indonesia \\ ${ }^{3}$ Department of Chemistry, Faculty of Mathematics and Natural Sciences, University of Sriwijaya, Inderalaya, Ogan \\ Ilir, South Sumatera,30662, Indonesia \\ ${ }^{4)}$ Department of Mine, Faculty of Engineering, University of Sriwijaya, kampus Inderalaya, Ogan Ilir, South Sumatera, \\ 30662, Indonesia \\ ${ }^{5)}$ Department of Soil, Faculty of Agriculture, University of Sriwijaya, kampus Inderalaya, Ogan Ilir, South \\ Sumatera,30662, Indonesia
}

*Email: hermansyah@unsri.ac.id

Accepted November 04, 2021 / Approved December 28, 2021

\begin{abstract}
Open-pit mining has affected landscapes and ecosystem balances immensely. The effects are including altered soil surface, decreased soil productivity, soil compaction, erosion and sedimentation, declined biodiversity, as well as deteriorated hydrological, hydrogeological, and atmospheric function of the surrounding area. Reclamation is one of the environmental restoration efforts that could be taken to improve these conditions. Physical and chemical properties of soil are the indicators of soil damage level as well as the success indicator of the reclamation program. This study aims to analyze the changes in post-mining soil characteristics after 5 years and 10 years of revegetation. The sample was selected by the purposive sampling method based on the age of plants and the vegetation density. The physical properties of post-coal soil after 5 years of revegetation are characterized by high soil acidity, low in organic matter (OM)/soil organic carbon (SOC), very low total $N$ (nitrogen), moderate $P$ availability, extremely high $\mathrm{K}_{2} \mathrm{O}$, and moderate $\mathrm{CEC}$. Whilst, the post-coal mining soil after 10 years of revegetation is found to be acidic (low $\mathrm{pH}$ ), with moderate $\mathrm{SOC}$, low total $\mathrm{N}$, low $\mathrm{P}$, very high $\mathrm{K}_{2} \mathrm{O}$, and moderate $\mathrm{CEC}$. Heavy metal (Fe, Mn, Al) contents in ex-coal mining reclamation area after 5 years and 10 years revegetation found to be in the high category.
\end{abstract}

Key words: post-mining land, revegetation, soil characteristics

\section{INTRODUCTION}

Open-pit system is the mining method generally used in coal extraction activities in Indonesia. The method was selected because coal reserves in Indonesia are mostly found close to the soil surface, thus open-pit mining is considered as the most effective and economical. Technically, the open-pit coal mining activities are involving land clearing, removal and hauling of soil and overburden materials, minerals excavation, and lastly, backfilling of ex-mining openings. (Aprilia, 2016), (Triantoro, 2017).

However, the open-pit system is indicated to have disrupted landscape and ecosystem balance. The damage is estimated to be 2-11 times higher than underground mining (Zhongke et al. 1999). Other effects are including soil surface alteration, decreased soil productivity, soil compaction, erosion, and sedimentation, declined biodiversity of flora, fauna, aquatic biota, as well as deteriorated hydrological, hydrogeological, and atmospheric function of the surrounding area. (Aprilia 2016; Favas et al. 2018; Ghose 2005; Haibin et al. 2010; Lestari et al. 2019; Munir et al. 2017; Subowo 2011); Toren 2002; Zhongke et al. 1999).
Considering these impacts, it is necessary to take efforts to recover the damaged ecosystem by applying various methods such as reclamation, restoration, rehabilitation, remediation, mitigation, etc. (Bradshaw 1996; Cooke et al. 2008; Venkateswarlu et al. 2016). Reclamation is the popular technique being used that comprising of backfilling, recontouring, drainage construction, erosion control, revegetation, acid mine drainage control, and plants maintenance (Febrianty 2015). Reclamation activities also take measures aiming at stabilizing post-mining soil, preventing erosion, and controlling runoff water pace, as well as protecting the land from instability and making it more productive (Yani 2005).

Chemical properties of post-mining soil without any reclamation treatment subjected to a decrease in $\mathrm{pH}$ up to 2.2-3.5 (Sheoran et al. 2010). This condition is in line with the research finding of Val and Gil (1994) in the excoal mining area in La Coruna Province, Spain, where the $\mathrm{pH}$ decreased to 4.1. Whilst in Central Coalfield Limited's (CCL), India the soil acidity was found to have dropped to 4.9 (Maiti and Ghose 2005). Mining operations also trigger a decline in soil fertility (organic 
matter), as indicated by the organic content of only $0.35 \%$. Whereas fertile soil has organic content of $0.75 \%$ (Ghosh et al. 1983). In addition, post-mining land generally contains $\mathrm{Cd}, \mathrm{Co}, \mathrm{Cu}, \mathrm{Cr}, \mathrm{As}, \mathrm{Mn}, \mathrm{Fe}, \mathrm{Pb}$ and Zn (Dowarah et al. 2009; Maiti et al. 2005; Saidy et al. 2013; Yaacob et al. 2009; Yenilmez et al. 2011) which are toxic to plants.

The physical and chemical properties of soil are indicators that signify the level of soil damage and the success of a reclamation program (Mukhopadhyay et al. 2014; Noviyanto et al. 2017). Ex-mining soil generally has a high acidity (low $\mathrm{pH}$ ), low water absorption rate, is poor in nutrients but high metal contents (Ayub et al. 2015). PT Bukit Asam, Tbk has conducted revegetation activities to improve the ecosystem in its ex-mining area starting from 2009. To observe the impact of revegetation activities on the physical and chemical characteristics of the soil, an analysis of soil characteristics of the post-mining area was carried out at the 5-year and 10-year-old revegetation sites. This study aims to analyze the changes in the characteristics of postmining soil after 5 and 10 years of revegetation.

\section{RESEARCH METHOD}

This research took place at PT. Bukit Asam Tbk, Tanjung Enim, Muara Enim District, South Sumatra Province, Indonesia specifically in its post-coal mining area that has been replanted for 5 years (lat $3^{\circ} 45^{\prime} 03.47^{\prime \prime}-$ $3^{\circ} 45^{\prime} 20.15^{\prime \prime} \mathrm{S}$ and long $103^{\circ} 47^{\prime} 07.13^{\prime \prime}-103^{\circ} 47^{\prime \prime} 26.37^{\prime \prime}$ E) and 10 years (lat $3^{\circ} 45^{\prime} 02.14^{\prime \prime}-3^{\circ} 45^{\prime} 11.82^{\prime} \mathrm{S}$ and long $\left.103^{\circ} 45^{\prime \prime} 10.69 "-103^{\circ} 44^{\prime} 29.67 ” \mathrm{E}\right)$.

Research sample was selected using the purposive sampling technique based on the age and density of the vegetation. The population of this study is 3.90 hectares of 5-year old revegetation plots (T-5) and 26.4 hectares of 10-year old revegetation plots (T-10).

The sampling selection started with categorizing the land based on vegetation density by overlaying Spot 6 satellite imagery and the revegetation map of the company using ArcGis software. The images classified using the delineation technique found three levels of vegetation density (i.e., high, medium, and low density) (BSN, 2014; Latuamury et al. 2016; Khairawan et al. 2020). The overlay and interpretation at T-5 areas discovered 2 (two) levels of vegetation density, 95\% of high density, and 5\% of medium density. As for the T-10 sites, there are three density levels: $71 \%$ of high density, $19 \%$ of medium density, and $10 \%$ of low density. Samples were taken at all density levels, covering the high, medium, and low density both from T-5 and T-10 locations (Table 1 and Figure 2). Samples were taken 2 times from each location at a depth of \pm 0.6 meters using a $10 \mathrm{~cm}$ diameter drill. Whilst, the intact soil samples were taken using a sample ring. The research variables measured were $\mathrm{pH}-\mathrm{H}_{2} \mathrm{O}$, organic matter $(\mathrm{OM})$, total $\mathrm{N}, \mathrm{P}$ availability, $\mathrm{K}_{2} \mathrm{O}, \mathrm{CEC}, \mathrm{Fe}, \mathrm{Al}$, and $\mathrm{Mn}$ contents.

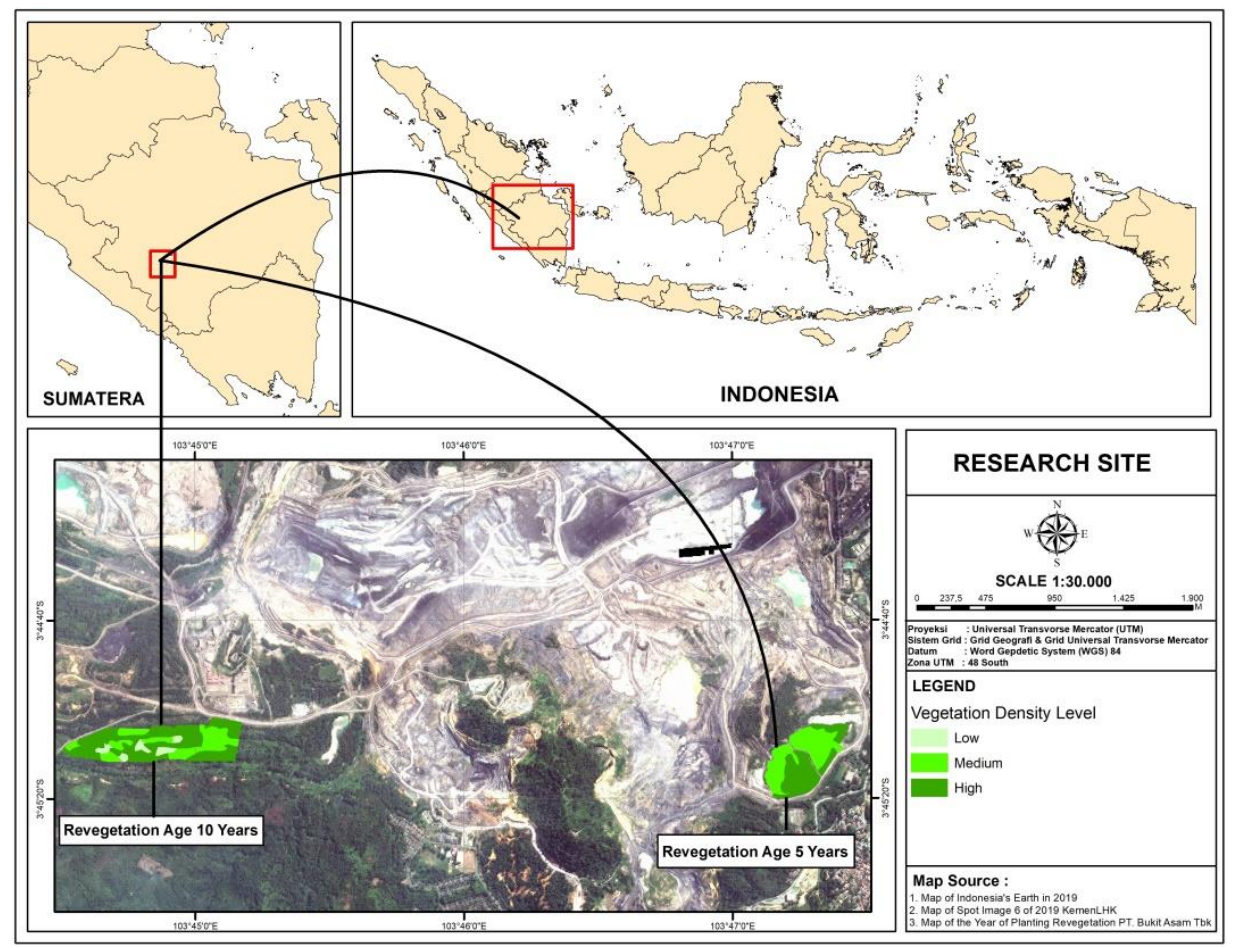

Figure 1 Map of research site consisting of 5-year and 10-year old revegetation area of PT. Bukit Asam, Tbk located in Tanjung Enim, Muara Enim District, South Sumatra Province, Indonesia that is part of West Block Management Area of Tambang Air Laya. 
Table 1 Soil sample distribution.

\begin{tabular}{|c|c|c|c|c|c|}
\hline \multirow{2}{*}{$\begin{array}{l}\text { Planting } \\
\text { Year* }\end{array}$} & \multirow{2}{*}{$\begin{array}{c}\text { Revegetation } \\
\text { age }\end{array}$} & \multirow[t]{2}{*}{ Plant Species } & \multicolumn{3}{|c|}{ Vegetation Density } \\
\hline & & & High & Medium & Low \\
\hline 2010 & 10 years & $\begin{array}{l}\text { Melaleuca cajuputi, Cassia siamea, Intsia palembanica, } \\
\text { Acacia mangium, Enterolobium cyclocarpum, Hibiscus } \\
\text { tiliaceus, Adenanthera pavonina }\end{array}$ & V & V & V \\
\hline 2015 & 5 years & $\begin{array}{l}\text { Enterolobium cyclocarpum, Shorea javanica, Intsia } \\
\text { palembanica, Aquilaria malaccensis, Delonix regia, Cassia } \\
\text { siamea, Delonix regia }\end{array}$ & V & V & - \\
\hline
\end{tabular}

Remark: *the revegetation started on the same year as the backfilling

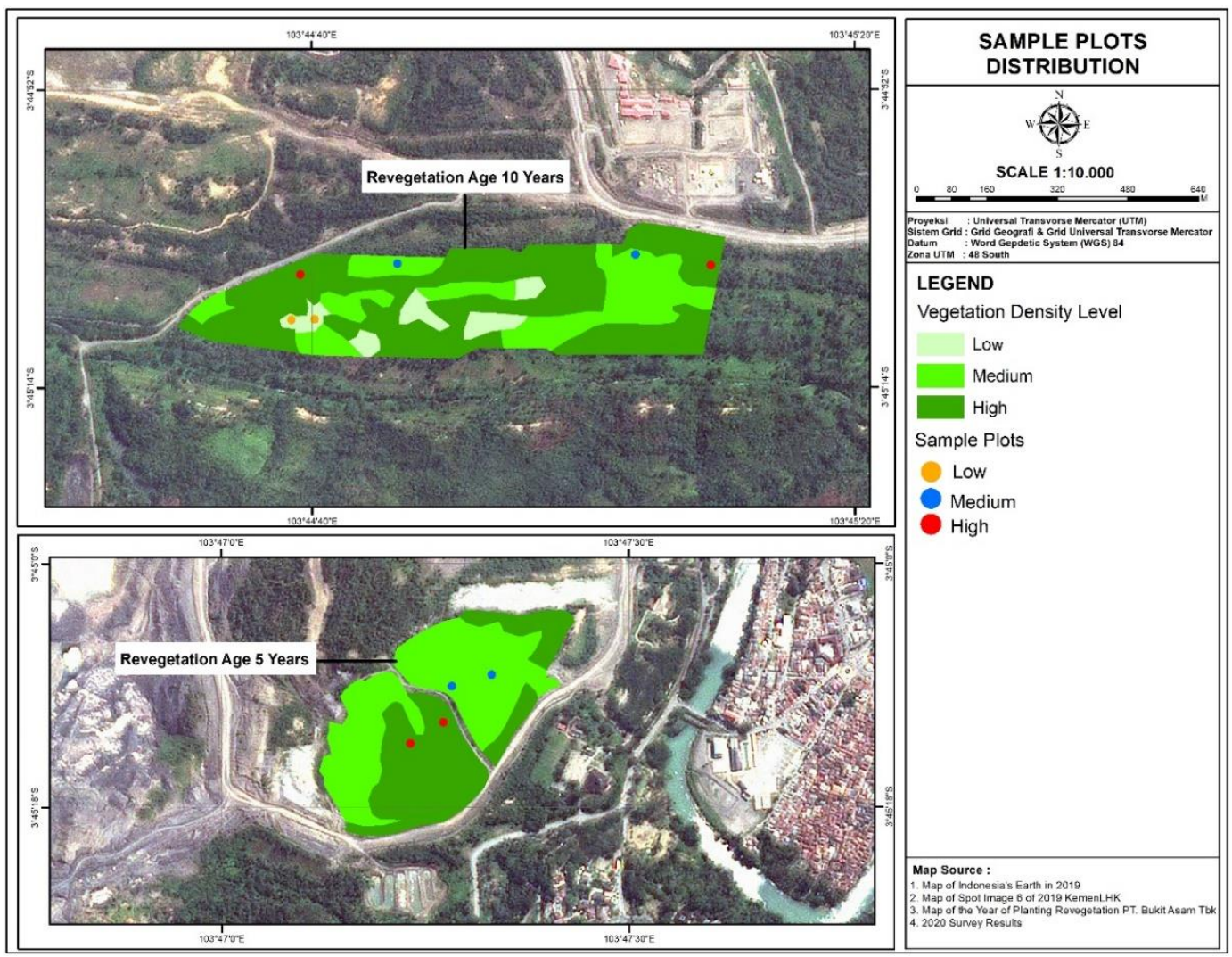

Figure 2 Soil sample distribution at high, medium, and low vegetation density both at 5-year and 10-year old revegetation sites.

Data needed for study analysis was collected through various measurement methods. Soil acidity $(\mathrm{pH}-$ $\mathrm{H} 2 \mathrm{O}$ ) was measured using electrometery method with a pH-Meter. Whilst, soil organic matter (OM) was analyzed using Walkey \& Black method with a spectrophometer. Total $\mathrm{N}$ was evaluated by Kjeldahl method using an Auto Distillation \& Auto Burette, while $\mathrm{P}$ availability was analyzed by Bray II method with a spectrophotometer. Next, $\mathrm{K}_{2} \mathrm{O}$ was examined by $\mathrm{HCI}$ $25 \%$ extraction method with flamephotometer; CEC determined by $1 \mathrm{M}$ Ammonium Acetate $\left(\mathrm{NH}_{4}\right)$ at $\mathrm{pH} 7$ with Automatic Burette. Lastly, DTPA (diethylenetriaminepentaacetic acid) extraction method is used for estimating the potential soil availability of heavy metal content ( $\mathrm{Fe}, \mathrm{Al}-\mathrm{dd}$, and $\mathrm{Fe}$ ). Fe substance measured and analyzed by DTPA extraction method using AAS, aluminum (Al-dd) analyzed by 1 M KCL titration method with a Burette, and manganese analyzed by DTPA extraction method using AAS.

\section{RESULT AND DISCUSSION}

\section{Backfilling Technique}

The stratification of Tanjung Enim coal seam is part of Muara Enim formation. This formation consists of three major groups, namely the overburden, main coal seam, and the interburden. The most dominant type of soil cover is claystone with gravel-sized sand, tuffaceous siltstone. The thickness of the overburden layer is between $80 \mathrm{~m}-150 \mathrm{~m}$ and is generally more than 120 meters. The overburden without or with little sulfide 
content can be assumed as non-acid forming (NAF/NonAcid Forming rock). Whereas, overburden with a higher amount of sulfide (less neutralizing agent, such as carbonate) has a higher acid-producing capacity, socalled Potentially Acid Forming Rocks (PAF).

The backfilling was carried out using the encapsulation method that started with PAF, NAF, and topsoil (humus). First, the PAF embankment compacted based on the results of a geotechnical study that meets safety requirements. Once the PAF compaction is finished, the PAF layer is covered/encapsulated with NAF layer. The NAF layer has also been compressed to a thickness of $3 m-5 m$ to allow it to be a protecting shield. Afterward, a layer of clay of approximately 1 meter thick was added to prevent the PAF from reacting with water and lower the potential of Acid Mine Drainage (AAT) formation. Finally, the NAF layer is covered with $0.5 \mathrm{~m}-$ $1 \mathrm{~m}$ of topsoil/humus without compaction. This topsoil containing nutrients is intended to be the planting medium for reclamation plants in the ex-mining area. The detailed flowchart of backfilling techniques is presented in Figure 3.

\section{Planting Media Treatment and Replanting Process}

The first step was spreading the topsoil onto the backfill materials prepared at the revegetation site. Then the soil acidity $(\mathrm{pH})$ was checked. If the $\mathrm{pH}$ is acidic $(\leq$ 5 ), the materials are then treated with lime as much as 3 tons/ha to lower the acidity until the $\mathrm{pH}$ improves in the range of 5.5-7.5. Acidity $(\mathrm{pH})$ is a very influential factor in plant growth in reclamation sites (Lestari et al. 2019). Another preparation is the civil construction of drainage to allow water flow and prevent inundation.

The plant species were selected from pioneer tree species and native superior woody species. Pioneer species such as Cassia siamea, Acacia mangium, Enterolobium cyclocsrpum, Adenanthera pavonina, and Delonix regia were planted during the initial stage of reclamation with $4 \times 4 \mathrm{~m}$ and $4 \times 6 \mathrm{~m}$ spacing. Except for Melaleuca cajuputi that was planted with $3 \times 3 \mathrm{~m}$ spacing due to its light canopy feature. Local superior plants (Intsia palembanica, Hibiscus tiliaceus, Shorea javanica and Aquilaria malaccensis) were planted after the pioneer plants has reached a minimum age of two years old. The size of the planting hole was $30 \times 30 \mathrm{~cm}$ with $25 \mathrm{~cm}-30 \mathrm{~cm}$ depth, with $\pm 3 \mathrm{~kg}$ of bokashi fertilizer added to the hole. When the planting conducted in the dry season, $\pm 1.5 \mathrm{~kg}$ of hydrogel then included to the hole. During the first three years of cultivation, plants maintenance is conducted every six months that including weeding, soil tiling, pests, and diseases controlling, fertilizing, and replanting the dead plants.

\section{Characteristics of Ex-Mining Soil}

The analysis of research results on $\mathrm{pH}-\mathrm{H}_{2} \mathrm{O}$, soil organic matter, total nitrogen $(\mathrm{N})$ and $\mathrm{CEC}$ values as well as the criteria presented in Table 2.

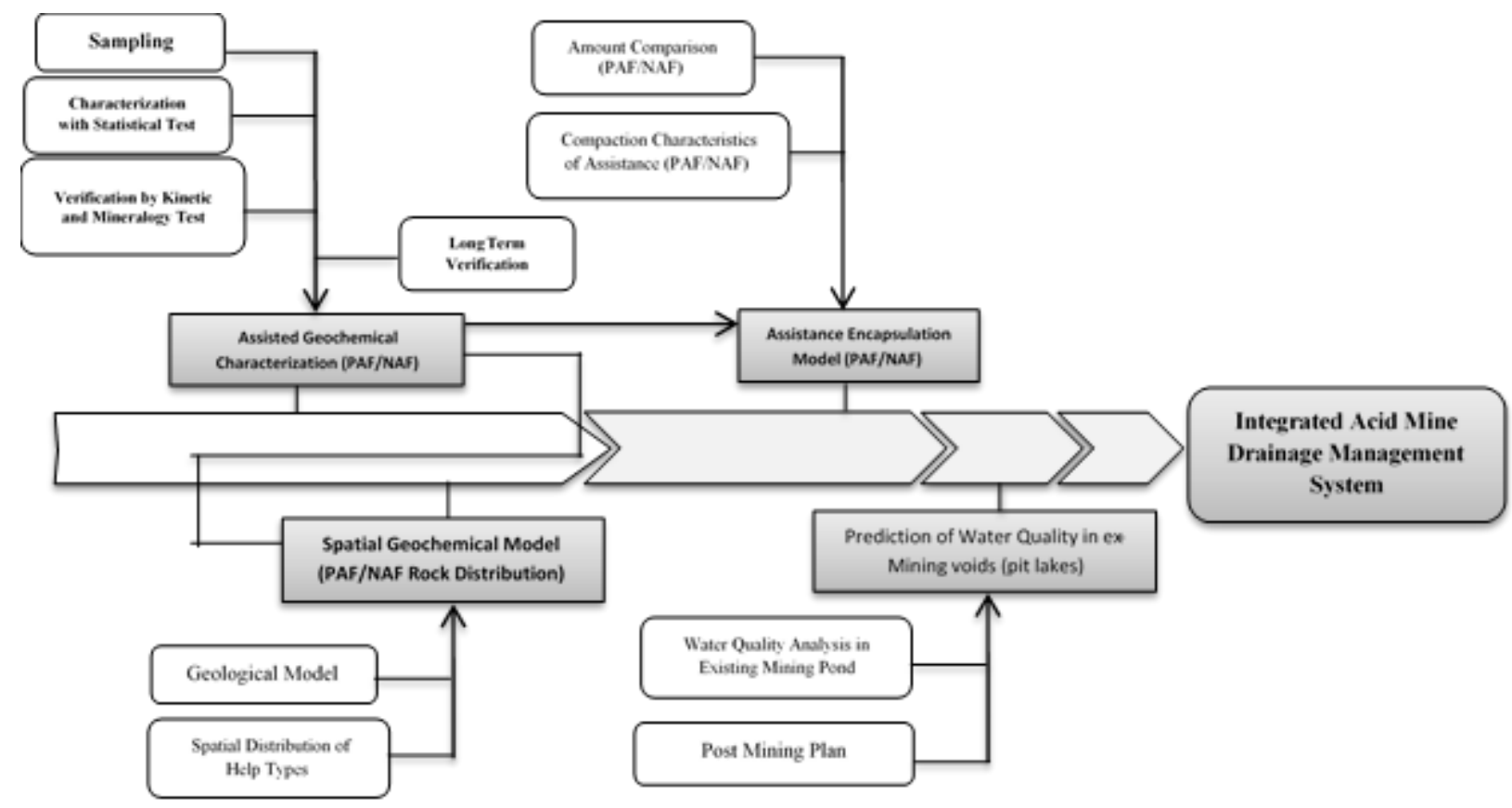

Figure 3 Backfilling technique/overburden management. 
Table 2 Chemical characteristics of the soil before and after mining activities

\begin{tabular}{lcccc}
\hline Indicator & $\mathrm{T}-0$ & $\mathrm{~T}-1$ & $\mathrm{~T}-5$ & $\mathrm{~T}-10$ \\
\hline $\mathrm{pH}-\mathrm{H}_{2} \mathrm{O}$ & 7.2 & 4.4 & 4.19 & 4.82 \\
Criteria & $\mathrm{N}$ & $\mathrm{HA}$ & $\mathrm{HA}$ & $\mathrm{A}$ \\
\hline OM (organic matter) (\%) & 1.77 & 2.68 & 1.41 & 2.60 \\
Criteria & $\mathrm{L}$ & $\mathrm{M}$ & $\mathrm{M}$ & $\mathrm{M}$ \\
\hline Total N (\%) & 0.12 & 0.27 & 0.09 & 0.17 \\
Criteria & $\mathrm{L}$ & $\mathrm{M}$ & $\mathrm{VL}$ & $\mathrm{L}$ \\
\hline Cation exchange capacity (CEC) (me/100gr) & 19.74 & 15.8 & 18.39 & 17.97 \\
Criteria & $\mathrm{M}$ & $\mathrm{L}$ & $\mathrm{M}$ & $\mathrm{M}$ \\
\hline
\end{tabular}

Source: Standar d Criteria of Indonesian Soil Research Institute (2009); (T-0) PT.Bukit Asam (2013); (T-1) PT.Bukit Asam (2020)

Remark: (T-0) pre-mining soil; (T-1 ) Initial backfill soil; (T-5) 5 years old revegetation soil; (T-10) 10 years old revegetation soil; (N) Neutral; (HA) High Acidity; (A) Acidic; (VL) Very Low; (L) Low; (M) Medium.

Based on the criteria established by the Indonesian Soil Research Institute (BPT), Center for Agricultural Land Resources Research and Development (2009), the acidity $(\mathrm{pH})$ found at research sites ranged from highly acidic to acidic with a $\mathrm{pH}$ of $4.19-4.82$. This $\mathrm{pH}$ value is below the standard acidity criteria for forest soil that is 6.4 (Jha and Singh 1991). There was an increase of $\mathrm{pH}$ in the soil as much as 0.63 or $15.04 \%$ at T-5 and T-10 sites (Figure 4). The improvement in the $\mathrm{pH}$ value was initiated by the revegetation process. The finding of Sheoran, et al. (2010) research stated that the chemical properties of post-mining soil without any reclamation treatment suffered a $\mathrm{pH}$ loss up to 2.2-3.5, which supports this hypothesis. This acidity level also indicates a higher improvement compared to the results of a study conducted by Rusdiana (2013) who analyzed the chemical characteristics of soil at the revegetation site aged 3 and 4 years that found $\mathrm{pH}$ values ranging from 3.60 - 4.40. Similarly, Val and Gil (1994) who researched post-coal mining sites in La Coruna Province of Spain found that the soil acidity dropped to 4.1 and to 4.9 in Central Coalfield Limited's (CCL) India, (Maiti and Ghose 2005). Likewise, research by Mashud, et al (2016) discovered that the $\mathrm{pH}$ value of post-coal mining soil ranges from $4.10-6.46$. Low acidity will cause a rapid decrease in the amount of macromineral elements such as phosphorus, potassium, calcium, and magnesium in the soil (Yamani 2012).

Organic matter is all carbon in the soil that comes from the remains of dead plants and animals, mostly plant tissue covered under the soil (Izzudin, 2012). The content of organic matter $(\mathrm{OM})$ at $\mathrm{T}-5$ sites was only $1.41 \%$ (low category), and $2.60 \%$ (medium category) at $\mathrm{T}-10$ sites. The range of $\mathrm{OM}$ values found in the research

The main sources of nitrogen in the soil are free nitrogen in the atmosphere, decomposition of organic materials, electric jumps in the air (lightning), as well as area is in agreement with the results of analysis by Mashud, et al. (2016) that found organic matter of postcoal mining area ranges from $0.48 \%-4.82 \%$. There was an increase in organic matter as much as 1.19 or $84.40 \%$ from T-5 to T-10 (Figure 4). The high amount of OM at $\mathrm{T}-10$ sites is potentially caused by the higher number of vegetation in the area. As stated by Hamid et al. (2017), older revegetation led to improved growth and diversity of vegetation that grows on replanted areas, so that the amount of organic matter produced increased accordingly, even though the amount is so low. Similar findings were also mentioned by Chaubey, OP et al (2012) and Yongguang, S et al (2011) who stated that the increase in soil organic matter on replanted land influenced by the form of the vegetation planted. When the surface of post-mining land is filled with dead leaves from planted vegetation, there will be an increase in soil moisture, and the leaf litter will be decomposed by soil microorganisms thus increasing the content of organic matter.

Total nitrogen $(\mathrm{N})$ content in soil of $\mathrm{T}-5$ sites is $0.09 \%$ (very low), and $0.17 \%$ (low) at $\mathrm{T}-10$ sites. The low amount of nitrogen in post-mining soil is also shown by the results of Adinda's research (2012), which found a total $\mathrm{N}$ between $0.03 \%-0.08 \%$ at a depth of $0-30 \mathrm{~cm}$ at several sample points and $0.03 \% .-0.06 \%$ at $30-60 \mathrm{~cm}$ depth. A study conducted by Jha and Singh (1991) found total $\mathrm{N}$ on post-mining soil after 5 years at $0.068 \%$; $0.074 \%$ after 10 years; $0.082 \%$ after 16 years; and $0.086 \%$ after 20 years. Our research found an increase of $88.89 \%$ in total nitrogen content at T-10 compared to T-5 (Figure 4). The improved total $\mathrm{N}$ value is due to a large amount of decomposed litter as one of the conditions for the humification process (Hamid et al. 2017).

artificial and organic fertilizers (Nurani et al. 2018). The amount of nitrogen contained in the atmosphere is extremely abundant, almost $78 \%$ of the total volume of 
the atmosphere, yet it is in elemental form thus it cannot be used immediately. Nitrogen must first be converted into ammonium or nitrate through certain processes. Free nitrogen enters the soil mainly through microorganisms' activities, either by fixation of nitrogen in free air or by a symbiosis of root nodules plants and rhizobium bacteria. The resulting nitrogen is then used in the synthesis of amino acids and proteins by the host plant. If the nitrogen-fixing plant or host dies, the spoilage bacteria release the amino acids from the protein (Nurani et al. 2018). Most of the nitrogen contained in the soil is an organic substance resulted by the decaying organisms, and some others are derived from the dissolution of rainwater (in the form of nitrate and ammonia) (Harahap. F et al. 2014).

CEC value of soils found at T-5 sites is 18.39 (meq/100gr) and 17.97 (meq/100gr) at T-10 locations. The CEC value indicates the ability of the soil to attract, retain or exchange cation elements in soil solution. Clay and organic matter that have negative electrical charges (ions) attract cations elements around it (in soil solution) so that an electroneutrality reaction occurs and results in a chemical balance. In practice, cation exchange is substantially affecting physical and chemical properties, fertility, and nutrient retention of soils, nutrient uptake by plants, as well as fertilization and liming aspects. The absorbed cations are generally available to plants through the cations exchange with $\mathrm{H}$ ions produced by the respiration of roots. Nutrients added to the soil in the form of fertilizer will be retained by the colloid surface. Winarso (2005) indicated that soils with higher clay content and/or high organic materials content have a higher CEC than soils with low clay content (sandy). Even though the cation exchange capacity criteria found in this study are classified as low and medium, but the CEC value is still higher compared to soils with low clay content. In line with this, Hardjowigeno (2007) explained that soil with a high CEC can absorb and provide nutrients better than soil with a low CEC. Organic materials that have been completely decomposed will promote the formation of humus colloid and improve the CEC value.

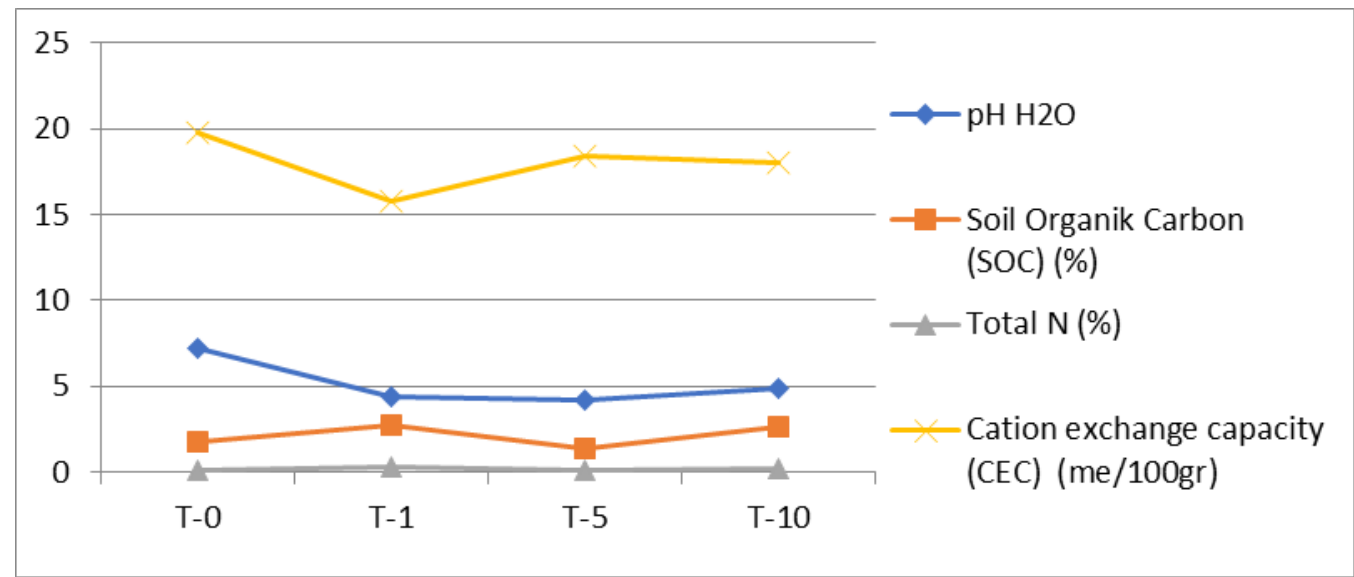

Remark: (T-0) Before mining; (T-1 ) Initial backfilling; (T-5) After 5 years of revegetation; (T-10) After 10 years of revegetation

Figure 4 Changes of $\mathrm{pH}$, soil organic carbon/organic matter $(\mathrm{OM})$, total nitrogen $(\mathrm{N})$, and cation exchange capacity (CEC) before mining activities, during initial backfilling, and after 5 years and 10 years of revegetation.

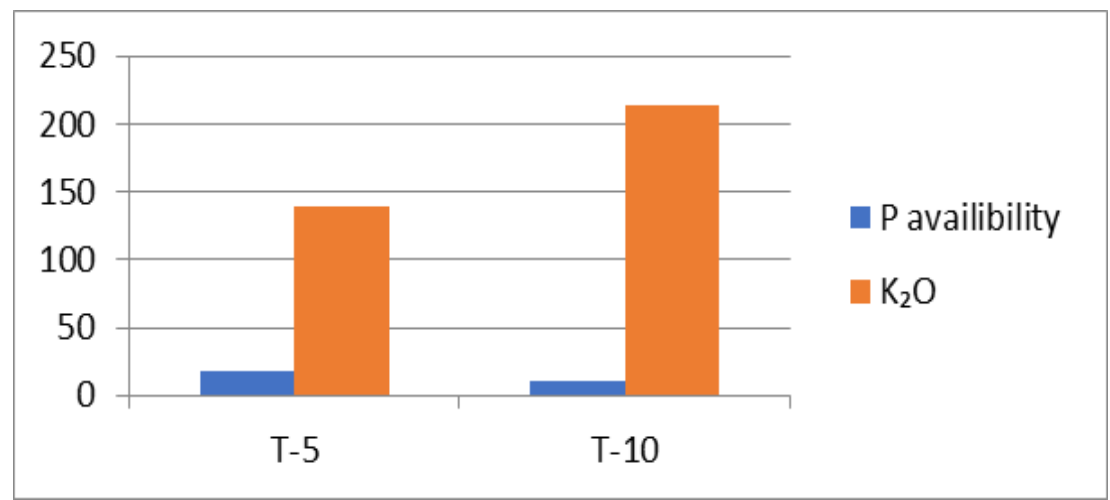

Remark: (T-5) Soils in 5 years old revegetation; (T-10) Soils in 5 years old revegetation

Figure $5 \mathrm{P}$ availability and $\mathrm{K}_{2} \mathrm{O}$ after 5 years and 10 years of revegetation. 
The value of $\mathrm{P}$ availability found at $\mathrm{T}-10$ research sites ranged from $4.5-22.64 \mathrm{ppm}$ that is in the very low to moderate category. Whilst, $\mathrm{P}$ availability at T-5 locations is $10.95-25.91 \mathrm{ppm}$ or in the low to moderate category. The range of $\mathrm{P}$ availability scores found by this research is better than the results of Adinda's research, (2012), which detected P availability content in the postmining revegetation site of PT. Vale Indonesia Tbk. Sorowako, South Sulawesi ranged from 3.50-4.60ppm at a depth of $0-30 \mathrm{~cm}$ and $3.10-4.30 \mathrm{ppm}$ at $30-60 \mathrm{~cm}$ depth. As the reclamation grew, the content of organic elements and $\mathrm{P}$ availability in the soil will be improved. Post-mining revegetation activities create a gradual improvement in soil properties due to the addition of organic matters (Hamid et al. 2017).

Vegetation requires $\mathrm{K}$ element (potassium) in large quantities. $\mathrm{K}$ is the second largest element after nitrogen (N). In fertile soil, $\mathrm{K}_{2} \mathrm{O}$ content is almost in a similar amount of $\mathrm{N}$. $\mathrm{K}_{2} \mathrm{O}$ is not a structural component in organic compounds. It is in ionic form, thus $\mathrm{K}+$ is mostly found dissolved in solution or bound by the negative charge of the soil surface layers. The main function of $\mathrm{K}_{2} \mathrm{O}$ is to activate enzymes and control water movement in the plant cell (Nurani et al. 2018). Analysis of soils at the 10-year old and 5-year old revegetation site found a very high amount of $\mathrm{K}_{2} \mathrm{O}$ content. The high level of potassium $\left(\mathrm{K}_{2} \mathrm{O}\right)$ plays a role in increasing resistance to plant diseases and promoting the root growth of plants (Syofiani et al. 2020). Soekamto (2015) explained that K ion $\left(\mathrm{K}_{2} \mathrm{O}\right)$ is an element that is easily washed off from the soil because $\mathrm{K}\left(\mathrm{K}_{2} \mathrm{O}\right)$ is not bounded tightly by the colloidal surface of the soil. The nature of $\mathrm{K}\left(\mathrm{K}_{2} \mathrm{O}\right)$ that is easily detached from the soil triggers low efficiency as in the $\mathrm{N}$ element. The level of potassium in soil is influenced by the major plant nutrients and soil $\mathrm{pH}$. Acidic soil led to a decline in the availability of $\mathrm{K}\left(\mathrm{K}_{2} \mathrm{O}\right)$ in the soil.

Iron $(\mathrm{Fe})$ content in the soil of $\mathrm{T}-5$ sites is 175.79 ppm, and $411.95 \mathrm{ppm}$ at T-10 (Figure 6) that are in the very high category according to BPT criteria (2009). Furthermore, T-5 soils are very acidic while T-10 soils are acidic. Fe solubility is affected by soil $\mathrm{pH}$, organic compounds, and bacteria contained in the soil (Gelyaman 2018). Acidity decrease will result in $\mathrm{Fe}$ surge because $\mathrm{Fe}(\mathrm{III})$ will be reduced to $\mathrm{Fe}(\mathrm{II})$ that can be induced by iron-oxidizing bacteria (Colombo et al. 2014).

T-5 sites were reported to contain $175.79 \mathrm{ppm}$ manganese, while T-10 have 411.95 ppm (Figure 6). Both are in the very high category according to BPT criteria (2009). The Mn serves as an activator of several enzymes, also in oxidases, peroxidases, dehydrogenases, and kinases that play a part in photosynthesis and nitrate reduction processes. Hydroxylamine reductase (enzyme) activity that promotes the conversion of $\mathrm{NO}_{3}$ to $\mathrm{NH}_{3}$ is subject to the presence of $\mathrm{Mn}$ in plant tissues. In addition, $\mathrm{Mn}$ is also an essential element in photosynthetic reactions, especially in the process of splitting water into free hydrogen and oxygen ions, metabolism of $\mathrm{N}$ and organic acids, carbohydrates reshuffling, as well as the formation of keratin, riboflavin, and ascorbic acid (Hassett and Banwart 1992; Gusmara 2016). Moreover, $\mathrm{Mn}$ is also an important component in chloroplasts and contributes to oxygengenerating reactions. If $\mathrm{Mn}$ solubility in the soil increases, the concentration of $\mathrm{Mn}$ in plant tissues will increase accordingly, causing excess Mn absorption by plants that may result in morphological abnormalities. The solubility of $\mathrm{Mn}$ is closely related to $\mathrm{pH}$ levels that possibly occur due to the oxidation-reduction reaction suffered by the element. In acidic soil, $\mathrm{pH}$ is always associated with the high solubility of $\mathrm{H}^{+}$ions. In weathered soil, compounds from the hydroxide group present in clay mineral complexes such as Al-hydroxy will release $\mathrm{Al}^{3+}$ ions into the soil solution and react with water that produces a source of soil acidity $\left(\mathrm{H}^{+}\right)$. Thus, when the solubility of $\mathrm{H}^{+}(\mathrm{pH}$ acid) in nature increases, Mn-oxide reduces. The increased solubility of divalent manganese under low $\mathrm{pH}$ will be immediately followed by symptoms of toxicity to plants. Lastly, Al content at T-5 sites is 3.58 and is 5.76 ppm at T-10, which based on BPT criteria (2009) is not harmful to the soil and plants growing on it.

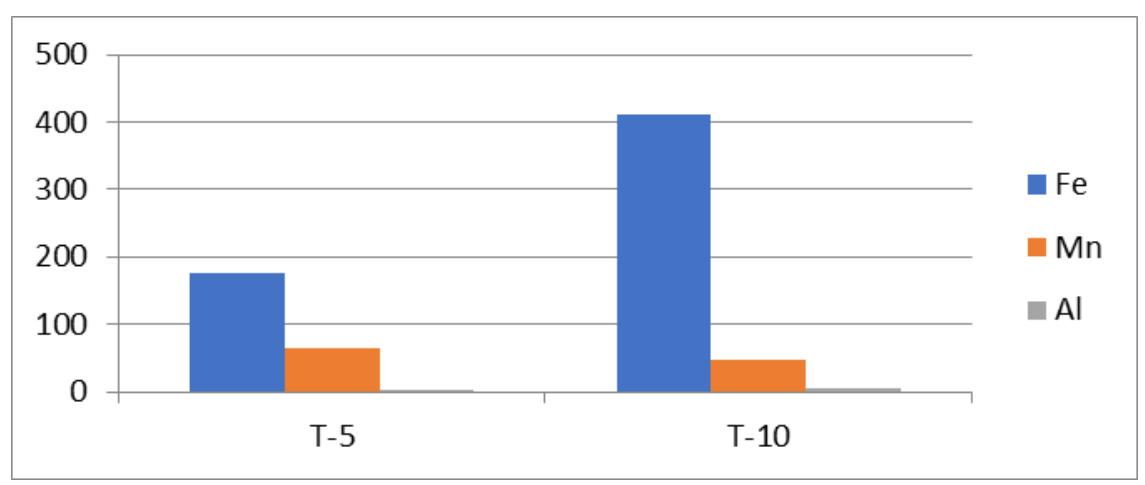

Remark: (T-5) : (T-5) Soils in 5 years old revegetation; (T-10) Soils in 5 years old revegetation Figure $6 \mathrm{Fe}, \mathrm{Mn}$, and $\mathrm{Al}$ levels after 5 years and 10 years of revegetation. 


\section{CONCLUSION}

The results of this study found that the physical characteristics of post-coal mining soil at 5-year-old revegetation sites are highly acidic, low in soil organic matter, very low total $\mathrm{N}$, moderate $\mathrm{P}$ availability, very high $\mathrm{K}_{2} \mathrm{O}$, and medium CEC. While the soils of T-10 (10-year-old revegetation) are acidic, have a moderate level of soil organic matter, low total $\mathrm{N}$, low $\mathrm{P}$ availability, very high $\mathrm{K}_{2} \mathrm{O}$, and medium CEC. The content of heavy metals (Fe, Mn, Al) in the 5-year-old and 10-year-old post-coal mining reclamation areas both are in the high category. Revegetation activities in an exmining area are part of conservation efforts that improve the physical and chemical characteristics of the soil.

\section{REFERENCES}

Adinda. 2012. Tree Growth Analysis on Post-Mining Revegatation Area of PT. Vale Indonesia Tbk. Sorowako, Sulawesi Selatan. Skripsi. Institut Pertanian Bogor. Bogor.

Aprilia S. 2016. Analysis Conformity The Former Land of The Coal Mines to PT Asia Multi Investama in Kabupaten Tebo Jambi. Promine. 4 (1): 17-27.

Ayub S.O, Widianarko Y.B, Izzati M. 2015. Dominance and Diversity of Forest Plant Species Growth on Post Coal Mining Soil in the Samarinda City, East Kalimantan Province, Indonesia. J. Biodivers. Environ. Sci. 6: 29-39.

BPT. 2009. Technical Manual for Chemistry Analysis of Soil, Plants, Water, and Fertilizer, 2nd ed. Balai Penelitian Tanah. Bogor.

Bradshaw A.D. 1996. Underlying Principal of Restoration. Can. J. Fish. Aquat. Sci. 53: 3-9.

BSN. 2014. SNI 7645-1:2014 Land Cover Classification - Part 1: Small and Medium Scale. SNI 7645-1, 151.

Chaubey O.P, Bohre P, and Singhal P.K. 2012. Impact of Bio-reclamation of Coal Mine Soil on Nutritional and Microbial Characteristics. International Journal of Bio-Science and Bio-Technology. Vol. 4 No. 3:69-80.

Cooke S.J, Suski C.D. 2008. Ecological Restoration and Physiology: An Overdue Integration. Bioscience 58: 957-968.

Colombo C., Palumbo G., He J.Z, Pinton R. \& Cesco S. 2014. Review on Iron Availability in Soil: Interaction of Fe Minerals, Plants, and Microbes. Journal of Soils and Sediments. 14 (3): 538-548.

Dowarah J, HP Deka Boruah, J Gogoi, N Pathak, N Saikia, A K Handique. 2009. Eco-restoration of a High-sulphur Coal Mine Overburden Dumping Site in Northeast India: A case study. J. Earth Syst. Sci. 118: 597-608.

Favas P.J de C, Martino L.E, Prasad M.N.V. 2018. Abandoned Mine Land Reclamation - Challenges and Opportunities (Holistic Approach), Bio-
Geotechnologies for Mine Site Rehabilitation. Elsevier Inc.

Febrianty D. 2015. Evaluation on the Success Rate of Reclamation Activities during Production Operation Stage at PT Bukit Asam (Persero), Tbk Unit Pertambangan Tanjung Enim. Skripsi. Universitas Sriwijaya. Palembang.

Gelyaman G.D. 2018. Factors Affecting the Bioavailability of Iron for Plants. J. Saintek Lahan Kering. 1: 17-19.

Ghose M.K. 2005. Soil Conservation for Rehabilitation and Revegetation of Mine-Degraded Land. TIDEE (TERI Information Digest on Energy and Environment). 4: 137-150.

Ghosh A.B, Bajaj J.C, Hasan R, Singh D. 1983. Soil and Water Testing Methods: A Laboratory Manual. IARI. New Delhi. 31-36.

Gusmara H. et al. 2016. Soil Science Basics ITN-100. Universitas Bengkulu Fakultas Pertanian. Bengkulu.

Haibin L, Zhenling L. 2010. Recycling Utilization Patterns of Coal Mining Waste in China. Resour. Conserv. Recycl. 54: 1331-1340.

Hamid I, Priatna S, Hermawan A. 2017. Physical and Chemical Characteristics of Soil in Ex-Tin Mining Area. J. Penelit. Sains. 19: 168165.

Harahap F, Nusyirwan. 2014. In Vitro Induction of Pineapple Shoots (Ananas comosus L. MERR) using Varied Doses of Auxins and Cytokines. J. Saintika. 15: 124-131.

Hardjowigeno, Sarwono, 2007. Soil Sciences. Penerbit Akademika Presindo. Jakarta

Hassett J.J and Banwart W.L. 1992. Soils and Their Environment. Prentice Hall. New Jersey.

Izzudin. 2012. Changes in Soil Chemical and Biological Properties Following Encroachment Activities in Reforestation Pine Forest Areas, Humbang Hasundutan Regency, North Sumatra Province. Skripsi. Institut Pertanian Bogor. Bogor.

Jha A.K, Singh J.S. 1991. Spoil Characteristics and Vegetation Development of an Age Series of Mine Spoils in a Dry Tropical Environment. Vegetatio. 97: 63-76.

Khairawan A, Falih N, Handoko T.D. 2020. Analysis of Vegetation Density Index Fluctuations using Landsat Imagery (Case Study: DKI Jakarta Province). Senamika. 1(2): 62-72.

Latuamury B., Resesi K. 2016. The Impact of Land Cover Vegetation Density on Hydrographic Recession Characteristics in Several Subwatersheds in Central Java Province and DIY Province. Majalah Geografi Indonesia. 26: 98-118.

Lestari D.A, Fiqa A.P, Fauziah, Budiharta S. 2019. Growth Evaluation of Native Tree Species Planted on Post Coal Mining Reclamation Site in East Kalimantan, Indonesia. Biodiversitas J. Biol. Divers. 20: 134-143. 
Maiti S.K, Ghose M.K. 2005. Ecological Restoration of Acidic Coalmine Overburden Dumps - An Indian Case Study. L. Contam. Reclam. 13: 361-369.

Maiti S.K, Nandhini S., Das M. 2005. Accumulation of Metals by Naturally Growing Herbaceous and Tree Species in Iron Ore Tailings. Int. J. Environ. Stud. 62: 593-603.

Mashud N., Engelbert D.A.N. 2016. Converting Ex-Coal Mining Area into Sago Plantation. Buletin Palma. 15 (1): 56-63.

Mukhopadhyay S., Maiti S.K, Masto R.E. 2014. Development of Mine Soil Quality Index (MSQI) for Evaluation of Reclamation Success: A Chronosequence Study. Ecological Engineering. 71: 10-20.

Munir M, Setyowati R.D.N. 2017. Reclamation Study on Post-Mining Area in Jambi, Bangka and South Kalimantan. Klorofil. 1: 11-16.

Noviyanto A, Minardi S. 2017. The Assessment of Soil Quality of Various Age of Land Reclamation After Coal Mining: A Chronosequence Study. J. Degrad. Min. Lands Manag. 5: 1009-1018.

Nurani, Rauf A, Jamilah. 2018. Evaluation of Soil Chemical Characteristics in Adolina Oil Palm Plantation of PTPN IV Serdang Bedagai in Several Planting Cohorts. Agroteknologi FP USU. 6: 1-13.

PT. Bukit Asam. 2013. Coal Mine Development Plan of PT. Bukit Asam (EIA Document).

PT. Bukit Asam. 2020. Ex-mining Plan of IUP Air Laya (Post Mining Plan Document)

Rusdiana O, Mulyana D, Willujeng C.U. 2013. Potential Carbon Storage Accounting of Acacia and Eucalyptus Stands in the Reclamation Area of PT. Bukit Asam (Persero) Tbk. J. Silvikultur Trop. 04: 183-189.

Soekamto M.H. 2015. Study on Soil Fertility Grade in Cocoa Plantation of Klain Village, Mayamuk District, Sorong Regency. J. Agroforestri. X: 201208.

Syofiani R., Putri S.D, Karjunita N. 2020. Soil Characteristics as the Determinant Factor of Agricultural Potential in Nagari Silokek National Geopark Area. J. Agrium. 17: 1-6.

Saidy A.R, Badruzsaufari. 2013. The Correlation of Cr(VI) Concentration and Soil Chemical Properties: Preliminary Information for the Rehabilitation of ExMining Area in South Kalimantan. J. Trop. Soils. 14: 97-103.
Sheoran V, Sheoran A, Poonia P. 2010. Soil Reclamation of Abandoned Mine Land by Revegetation: A Review. Int. J. Soil, Sediment Water. 3: 1-20.

Subowo G. 2011. Environmental-Friendly Open-pit Mining System and Post Mining Reclamation Activities to Improve the Quality of Land and Soil Biological Resources. J. Sumberd. Lahan. 5: 83-94.

Toren T. 2002. Determination of Environmental Impacts due to Open Pit Coal Mining Activities: A Case Study From Turkey. Proc. SWEMP. 7-10.

Triantoro A. 2017. Study on Land Reclamation of ExCoal Mine of PT. Bhumi Rantau Energi in Rantau, South Kalimantan. Geosapta. 3: 107-110.

Val C, Gil A. 1994. Methodology for Monitoring Land Reclamation of Coal Mining Dumps. In: America Society of Mining and Reclamation. 2-11.

Venkateswarlu K, Nirola R, Kuppusamy S, Thavamani P, Naidu R, Megharaj M. 2016. Abandoned Metalliferous Mines: Ecological Impacts and Potential Approaches for Reclamation. Rev. Environ. Sci. Biotechnol. 15: 327-354.

Winarso S. 2005. Soil Fertility as the Basis of Soil Shape and Quality. Gava Media. Yogyakarta.

Yaacob W.Z.W, Pauzi N.S.M, Mutalib H.W. 2009. Acid Mine Drainage and Heavy Metals Contamination at Abandoned and Active Mine Sites in Pahang. Bull. Geol. Soc. Malaysia. 55: 15-20.

Yamani A. 2012. Analysis on Soil Macro Nutrient Levels in the Mount Sebatung Protected Forest in Kotabaru Regency. J. Hutan Trop. Borneo. 12.

Yani M. 2005. Ex-Mining Land Reclamation by planting Jatropha (Jaropha curcas Linn). Pusat Penelitian Surfaktan dan Bioenergi LPPM-IPB. Bogor.

Yenilmez F, Kuter N, Emil M.K, Aksoy A. 2011. Evaluation of Pollution Levels at An Abandoned Coal Mine Site in Turkey with The Aid of GIS. Int. J. Coal Geol. 86: 12-19.

Yongguang S, Xiuzhen L, Mander U, Yanlong H, Yuel J, Zhigang M, Wenyong G, and Zaijun X. 2011. Effect of Reclamation Time and Land Use on Soil Properties in Changjiang River Estuary, China, Chin. Geogra. Sci Vol 21. No. 4:403-416.

Zhongke B, Jingkui Z, Jinchuan L. 1999. Ecosystem Damage in A Large Opencast Coal Mine - A Case Study on Pingshuo Surface Coal Mine. Acta Ecol. Sin. 19: 870-875. 